\title{
Astronomy, Illumination and Heritage: the Arles-Fontvieille megalithic monuments and their implications for archaeoastronomy and world heritage
}

\author{
Morgan Saletta \\ History and Philosophy of Science, University of Melbourne \\ Victoria 3010, Australia \\ email: msaletta@unimelb.edu.au
}

The Arles-Fontvieille monuments, or hypogées, have long had a special place in megalithic studies. Their unique architecture, blending "Atlantic" megalithic construction with subterranean rock-cut architecture more commonly found in the Mediterranean, and their size, especially that of the Grotte de Cordes, place them among the most important monuments in France and Europe (Daniel 1960, Guilaine 1998, Sauzade 1999, Hoskin 2001, Saletta 2014). My discovery and interpretation of seasonal light and shadow hierophanies (Saletta 2011, 2014)) within the Arles-Fontvieille monuments has important implications for identifying astronomically related Outstanding Universal Value for late prehistoric European monuments.

Despite much discussion of illumination hierophonies, most archaeoastronomers investigating late prehistoric European monuments continue to think in terms of the "celestial targeting hypothesis" - assuming a monument's orientation is targeting a celestial body at some point in the sky, generally on or near the horizon (Saletta 2014). This, and the often implicit focus on astronomically important dates such as the equinoxes or solstices, etc., is an enduring influence of the now rejected Thom paradigm. In the context of the monumental landscape of Orkney, where, as in Europe more generally, many monuments show no such calendrically significant orientation, Downes \& Richards 2005 suggest that seasonal illumination of chambered monuments at different times was creating an "ancestral time". Such "ritual time" (Bloch 1977) is often associated with ritual feasting, which has been proposed by many researchers as playing a part in the construction and use of megaliths and other monuments in late-prehistoric Europe (e.g. Renfrew 1973; Tilley 1996). Numerous cross-cultural ethnographic examples also suggest a link between astronomy, time-reckoning and ritual feasting (Hayden \& Villeneuve 2011).

Furthermore, multiple lines of evidence suggest a cosmologically symbolic link between houses of the living and houses of the dead in later prehistoric Europe (Ruggles 2010). Solar orientation of domestic architecture for functional purposes (i.e. lighting and heat) has also been suggested as an explanation for the orientation patterns of Neolithic domestic structures (Topping 1996). Thus the solar orientation and illumination in monuments may have originated in a functional orientation of domestic architectures which took on symbolic significance and was then incorporated in the houses of the dead.

The similarity of the seasonal illumination of the Arles-Fontvieille monuments with the illumination events at Newgrange in Ireland and Maeshowe in Scotland, suggests that astronomical orientation and seasonal illumination of monuments were part of widely shared cosmological beliefs and practices related to monumentality in late prehistoric Europe (Midgley 2008). Illumination hierophanies in monuments with passages and chambers 
occur for a number of days and thus produced a ceremonial time period, rather than marking a precise date. The wide range of regional monumental orientations may have produced what Dwyer (1990) has termed social synchrony by distributing seasonal rituals spatially and temporally, thus helping to organize ceremonial and seasonal ecological activities. In interpreting these orientations, and assessing their astronomically related heritage value, archaeoastronomers need to move beyond the celestial targeting paradigm to a more anthropological approach to astronomical orientation and seasonal illumination within late prehistoric European monuments.

\section{References}

Bloch, M. 1977, Man, 12, 278

Daniel, G. E. 1960, The Prehistoric Chamber Tombs of France: A Geographical, Morphological, and Chronological Survey (London: Thames and Hudson)

Downes, J. \& Richards, C. 2005, in: C. Richards (ed.), Dwelling among the monuments: the Neolithic village of Barnhouse, Maeshowe passage grave and surrounding monuments at Stenness, Orkney (Cambridge: McDonald Research Monograph), p. 57

Dwyer, P. D. 1990, The Pigs That Ate the Garden: a Human Ecology from Papua New Guinea (Ann Arbor: University of Michigan Press)

Guilaine, J. 1960, Au temps des dolmens: mégalithes et vie quotidienne en France méditerranéenne il y a 5000 ans (Toulouse: Ed. Privat)

Hayden, B. \& Villeneuve, S. 2011, A. Rev. Anthropol., 40, 433

Hoskin, M. 2001, Tombs, Temples and their Orientations : a New Perspective on Mediterranean Prehistory (Bognor Regis: Ocarina Books)

Midgley, M. S. 2008, The Megaliths of Northern Europe (London: Routledge)

Renfrew, A. C. 1973, Before Civilization: The Radiocarbon Revolution and European Prehistory (London: Jonathan Cape)

Ruggles, C. L. N. 2010, in: C.L.N. Ruggles \& M. Cotte (eds.), Heritage Sites of Astronomy and Archaeoastronomy in the context of the UNESCO World Heritage Convention (Paris: ICOMOS -IAU), p. 28

Saletta, M. 2011, in: C.L.N. Ruggles (ed.), Archaeoastronomy and Ethnoastronomy: Building Bridges between Cultures (Cambridge: Cambridge University Press), p. 364

Saletta, M. 2014, in: X. Margarit et al. (eds.), Les monuments mégalithiques d'Arles-Fontvieille, État des connaissances, contextes et nouvelles données (Aix-en-Provence: DRAC-SRA de PACA, Lampea), p. 143

Sauzade, G. 1999, in: J. Guilaine (ed.), Mégalithisme de l'Atlantique à l'Éthiopie (Paris: Errance), p. 125

Tilley, C. 1996, An Ethnography of the Neolithic: Early Prehistoric Societies in Southern Scandinavia (Cambridge: Cambridge University Press)

Topping, P. 1996, in: T. Darvill, \& J. Thomas (eds), Neolithic Houses in Northwest Europe and Beyond (Oxford: Oxbow Books), p. 157 